\title{
Challenging the meaning of the past from below: A typology for comparative research on memory activists
}

Memory Studies $1-17$

(C) The Author(s) 2021 Article reuse guidelines: sagepub.com/journals-permissions DOI: 10.1177/17506980211044696 journals.sagepub.com/home/mss

\section{Yifat Gutman}

Ben-Gurion University of the Negev, Israel

\author{
Jenny Wüstenberg
}

Nottingham Trent University, UK

\begin{abstract}
Memory activists have recently received more scholarly and public attention, but the concept lacks conceptual clarity. In this article, we articulate an analytical framework for studying memory activists, proposing a relatively narrow definition: "Memory activists" strategically commemorate the past to challenge (or protect) dominant views on the past and the institutions that represent them. Their goal is mnemonic change or to resist change. We locate scholarship on memory activists at the intersection of memory studies and social movement studies. We introduce a typology for comparative analysis of memory activism according to activist roles, temporality, and modes of interaction with other actors in memory politics, and illustrate this with a diverse set of empirical examples. We contend that the analytical utility of the concept of the "memory activist" is premised on its value-neutrality, and in particular, its application to both pro and anti-democratic cases of activism.
\end{abstract}

\section{Keywords}

democracy, memory politics, mobilization, movements, populist, progressive

In 2020, efforts to remove statues and place names glorifying colonial and racist legacies have dominated news headlines - and have in turn evoked counter-protests, as well as government action. We have also heard louder calls for established institutions to reconsider their role as guardians of national history and to instead foster active citizen engagement in the present. Thus, we are currently experiencing an unprecedented period of activism in memory politics. Memory studies have recently begun to pay more attention to "memory activism" and the concept has been used in a wide variety of contexts. However, memory activism is neither new nor is it useful to apply the term to all situations in which the politics of the past appear contentious. The significance of struggles over memory in times of heightened mobilization necessitates a clear conceptualization of memory activism that allows systematic and comparative analysis. This is what we set out to do in this article: to articulate an analytical framework for identifying and studying memory activists as significant social actors, using a relatively narrow definition. 
The article begins by offering a definition of the "memory activist" as an agent (individual or group) who strategically commemorates the past in order to publicly address the dominant perception of it. Memory activists use memory as the crucial way of transforming society from below. Memory activists identify as non-state actors, but their efforts can also be directed at defending the status quo or official historical narratives from change instigated by others. We then situate our notion of memory activists in the literature on memory, activism, and social movements, carving out a particular approach that builds on, but is also distinct from, existing scholarship. Next, we introduce a typology of memory activists, which draws on our own empirical research, as well as that of others - most notably on work presented in the forthcoming Routledge Handbook of Memory Activism. As we then illustrate, this analytical tool enables a systematic study of diverse cases of memory activism, and raises new questions for future scholarship.

The stakes of this article are first and foremost analytical. Like many scholars, we believe that certain kinds of memory activism can do much to invigorate democracy, while other kinds may pose a danger against which we want to work as citizens. However, we argue that a systematic study of memory activists needs to capture not only progressive, but also populist and "uncivil" civil society groups (Alexander, 2006). Thus, our "value-neutral" definition of the memory activist overcomes a progressive bias in existing studies of memory activism and is essential for a comprehensive understanding of how memory "from below" contributes to political transformation.

\section{The memory activist}

The term memory activism has been conceptually stretched to encompass a wide range of actors and instances of contention, from administrators and government officials, to historians, artists, and a variety of social movements (Dybris McQuaid and Gensburger, 2019; Hajek, 2013; Harris, 2006; Pettai, 2020; Rigney, 2018; Bukowiecki et al. 2020; Whitlinger, 2019; Zamponi, 2018). A clear definition is therefore essential. We define memory activists as actors (individual or collective), who engage in the strategic commemoration of the past in order to achieve or prevent change in public memory by working outside state channels. Let us explain each part of this definition.

A memory activist can be an individual actor or a group of people, organized formally in associations, or at various levels of informality. Thus, we include organized protest actions, as well as one-off, spontaneous and ephemeral efforts to engage public memory and regard those actors as memory activists in this situation. "Memory activist" is therefore a broader and, at the same time, narrower category than a "memory movement"; it is broader because it includes informal protest whereas social movement scholars usually regard "a movement" as a sustained, organized, and repeated action that requires enduring commitment from its members (Bennett and Segerberg, 2013). And it is narrower, because social movements or other types of collective action can operate as memory activists at particular moments-like \#Blacklivesmatter activists, when they target Confederate or other racist statues - even though they may not be memory activists in other situations. Memory practices like removing statues, which link present events to the systematic historical injustice against African Americans, are part of the larger, non-memory activist effort. Moreover, memory activism in our definition does not necessarily entail collective action in a traditional sense (Tarrow, 1998) — some of the most effective or at least publicity-savvy memory activists operate alone-like Emir Hodžić, a genocide survivor, who stood alone on a Bosnian public square in 2012 to protest a ban on commemoration, which spurned the \#whitearmbandday memory campaign on social media (Fridman and Ristić, 2020).

Our definition also insists that "memory activism" denotes strategic action that explicitly targets public memory, because activists see it as a unique platform for changing the present view of the 
past. Strategy is not only a political practice for informed or calculated decision-making but also a socio-cultural practice that is used in everyday life to achieving smaller and larger goals (Jasper, 2004; Swidler, 1986). While activity that is located in the sphere of civil society is sometimes nonstrategic (i.e. not oriented toward particular objectives), we believe that the identity of memory activists is wrapped up in the idea of pursuing defined goals (irrespective of their success). Nonstrategic interventions may also be significant to the shaping of public remembrance, but they remain outside the framework of memory activism. While non-human actors (archives, memes, algorithms) are also involved in shaping the public utilization of memory (Smit, 2020; van Dijck, 2007), we do not see their involvement as diminishing the significance of human actors' intention and motivations as a necessary part of memory activism.

Memory activists work for change in public memory. Collective memory is a site of political struggle where different stakeholders compete for legitimacy for their interpretations of the past. Through publicly airing their representations of the past, stakeholders also address different publics or form counter-publics (Warner, 2005) and seek legitimacy for their interpretations of the past (Wagner-Pacifici and Schwartz, 1991). Participating in memory activism, therefore, entails taking a public stance vis-à-vis other actors in public space rather than commemorate privately inside the home or within the family.

There is of course much remembering that takes place in private and this plays an important role in our communicative and cultural memory (Assmann, 2010). However, unless this work is turned toward transforming the public narrative about the past, it is not memory activism. An exception here is private commemorative work that is held in the absence of safe public mnemonic spaces: clandestine remembering by counter-publics (Warner, 2005). Here, we argue that such clandestine memory work operates within alternative public spheres, and is therefore defined as memory activism, because its ultimate goal is transforming a community's public approach to the past. As circumstances change and conditions become less risky, memory activists can emerge from the shadows and draw on the work done clandestinely. An example is memory activism of the Ndebele people of Zimbabwe of the 1980s genocide, which takes place in password-protected websites, as well as family and community events such as funerals (Mpofu, 2014).

Memory activists use practices of remembrance because they view memory as a unique platform for change due to the transformative character of memory work. Memory work is a type of "activity that generates and transforms the social world" that occurs "when human beings are actively involved in the processes of symbolic transformation and elaboration of meanings of the past" (Jelin, 2003 5). This transformative character of memory work manifests itself not only when activists seek to counter and revise the dominant, but also in those who wish to guard against change by reproducing the dominant view of the past. As memory is never static and always in need of activation, even preserving the dominant view of the past requires rearticulating or even reinventing it (Gans, 1997). Both memory activists who work for changing the dominant memory and those who work against such change are similarly active in utilizing memory for transformation of symbolic meanings.

Memory activists are explicitly defined as non-state actors, acting to challenge state policies or official public memory, though their efforts can also be directed at defending official historical narratives from change instigated by others. We believe that the designation as "non-state" is important in order to distinguish such "grassroots" or non-elite efforts from other actors in memory politics. Memory activism is organized "from below." Thus, actions by members of the state or elites, or by academic experts like historians and archeologists, that influence a community's understanding of its past are not defined as memory activism. The work of an historian qua historian is crucial for how a society understands its past, but it is not activism. If a university or a museum adopts a policy or commissions an exhibition that challenges the mnemonic status quo, then this may be a significant development in the politics of memory, but we do not see it as 
activism. As Bill Niven suggests, activists by their very nature act outside and vis-à-vis the state, as the state (albeit not being a monolithic entity) cannot be active against or outside itself by its very definition as the established order. When protest against state government or institutions increases, state actors may respond with provocative and defiant actions to oppose such views that come from outside state channels. Or they may be supportive of defiant actions. They may even join the protests as private citizens. But this does not make state officials and institutions into "activists" per se. ${ }^{1}$ In other words, memory activists can strongly influence the state, and they can even eventually become part of the state itself, but at this point, they are no longer defined as memory activists. As Jenny Wüstenberg (2017) has argued, our analysis of memory activism is "built on the assumption that the boundary between state institutions and civil society is a category of practice. Actors define and imagine this boundary through their contentious interaction. The boundary is thus real and meaningful, but not static" (p. 28, see also Brubaker, 1996; Mitchell, 1999). Thus, the "non-stateness" is a crucial part of the identity of activists, even when individuals may take on roles and arguments that straddle this divide.

Finally, we do not include purely for profit work in our definition of memory activism. Of course, there are many examples of activists with a dual motive of influencing public memory while also making a profit (Björkdahl and Kappler, 2019; Buda, 2015). However, non-state actors whose primary motive is profit - taking advantage of a demand for public history, without a goal for changing memory in one direction or another - are not considered memory activists. For example, the creators of the "DDR Museum" in downtown Berlin have no doubt influenced how the past is represented. But they have done so by reacting to touristic demand, rather than in order to achieve change - the Museum's founder unabashedly told Wüstenberg (2017) that the Museum was purely a business endeavor.

In the next section, we show how our definition of memory activists builds on, but is also distinct from, existing scholarship.

\section{At the nexus of movements and memory}

Within the field of memory studies, the question of "who" qualifies as a memory activist emerges very much from the empirical case(s) at hand and so there are a few generally applicable definitions. Much of this research has strong normative connotations that assumes that memory activism is driven by an inexorable need on the part of those involved or that it is inherently "progressive." For instance, Ann Rigney (2018) argues that "the memory-activism nexus is a complex one, a vortex of recycling, recollection and political action that can be summed up as "civic memory"" (p. 372). Given her focus on the positive role of remembering protest actions as moments of hope, which inform the present struggle for a better life, the civic nature of memory or activism in Rigney's understanding makes sense. However, this would be too narrow of an assumption for the "memory activist," in general (see also Holc, 2018; Kovras, 2017: 6; Szczepanka, 2014: 2). Indeed, memory activism can be "agnostic" in its politics, proving an amplifier of pre-existing motivations. Carol Gluck (2007: 57) observes this regarding Japan's shifting memory of the Second World War, writing that memory activist groups work for a variety of goals and ideas, including for and against reconciliation and commemoration. Joanna Wawrzyniak (2015: 22) provides an important example of research on memory activists that pursue all kinds of causes - including fascist, communist, and pacifist. Of course, scholars who study progressive memory activists usually do not deny that memory activism can also be undertaken by non-progressives. Rather, this issue is not raised and so, we contend, that memory researchers' progressive bias is not so much a matter of explicit design, but committed by collective omission.

Because many scholars of memory are motivated by their commitment to a democratic and nonviolent politics, they are often primarily interested in studying activists with "emancipatory" 
agendas. The utility of our concept of "memory activism," we suggest, is its value-neutrality, because it also encapsulates initiatives that challenge democratic and egalitarian values. Memory activism provides us with the necessary analytical purchase to investigate and compare the beliefs, tactics, and opportunity structures of activists from across the political spectrum.

Recently, both memory and social movement scholars have shown a heightened awareness of how the two fields inform one another in crucial ways. Thus, in a recent addition to the debate, Stefan Berger et al. (2021) identify five areas of research that are particularly fruitful for "a more integrated and cross-interdisciplinary treatment of memory activism: repertoires, historical events, generations, collective identities and emotions" (p. 7). Priska Daphi and Lorenzo Zamponi (2019) identify three main strands of research, though they stress that all of them interact and overlap in practice (also see Wicke, 2021, for a categorization along similar lines). The first, "memories of movements" focuses on how past social movements are remembered in society writ-large. Scholars analyze mnemonic change and the conditions for why certain protest events and movements have been successfully remembered in society while others have been forgotten (Armstrong and Crage, 2006; Chidgey, 2015; Hajek, 2016; Pearce, 2015; Rigney, 2016; Whitlinger, 2019). The second strand, Daphi and Zamponi argue, examines "memories in movements" or how memories of various pasts affect a movement's internal functioning and cohesion. Studies have shown how memories determine dynamics of contention (Bosco, 2004), provide symbolic resources and points of orientation that influence movement framing (Baumgarten, 2017), built movements' identity (Daphi, 2017; Gongaware, 2011; Polletta and Jasper, 2001), and repertoires of contention (Zamponi, 2018). Memory is viewed as "a cultural resource out of which activists draw symbols and ideas" (Kubal and Becerra, 2014: 872), or as one of several "cultural building blocks" for a movement's collective identity (Daphi, 2017; Polletta and Jasper, 2001: 299). Here, memory is utilized for movements' internal purposes rather than to publicly address society's view of its past and present.

The third category - "movements about memory"-denotes a particular type of movement and a particular objective for the movement. Research on movements about memory explore "how they mobilize around the reinterpretation of the past and how they participate in the construction of public memory about past contentions and other historical events" (Daphi and Zamponi, 2019: 403). Interestingly, throughout their discussion of the memory-movement nexus, Daphi and Zamponi at times use the term "activism" interchangeably with movements.

Our conception of memory activism does not include considerations of how movements are remembered, nor whether or how movements draw on the past to organize and identify. And so, our concept of memory activism is most closely related to the strand of "movements about memory," with some important differences. First, we purposely use the term "memory activism" rather than "memory movements" in order to be more inclusive than a classic definition of a social movement, which, as mentioned, is premised on the idea of collective and organized action, sustained over time. Memory activists can be gathered in movements or formal civic organizations, but they may also be lone individuals or small groups, and they may act spontaneously, in an ad hoc fashion, or only once or twice to achieve mnemonic change. Despite this difference, some scholars seem to use "movements" and "activism" synonymously, when they discuss the activist utilization of particular memories (see, for example, Merrill et al., 2020: 4). The second way in which our definition of memory activism differs is based on the role that memory plays. "Movements about Memory" (Daphi and Zamponi, 2019) and Merrill et al.'s (2020) "memory activism" are concerned with memory as the outcome of activism. This is a central part of our definition as well. However, we would say that for memory activists, different activities to remember the past are both the practice and the objects of contentious action. 
Unlike "movements about memory" or Merrill et al.'s definition of memory activism, the objective of "memory activists" as we define them, is not limited to mnemonic change, but can address larger societal change of norms and policy. All memory activists use memory as means, but some of them also target memory as their aim; they wish to change or defend the dominant meaning of a certain past in the present. Shaping a society's public memory can range from influencing the physical landscape of commemoration, to reframing public narrative and changing official policies regarding the past. Other memory activists target broader societal changes as the primary goal, and actors qualify as memory activists only if they see and use memory practices as their core approach to achieving (or preventing) that change. Whether activists seek a mnemonic or political outcome, deploying memory as a practice is political - as activists engage in the symbolic change of meaning in the world (Jelin, 2003). The type of mobilization that stems from viewing memory as transformative in and of itself can be called memory activism, and it is far less studied and theorized.

\section{A typology for studying memory activists}

We operationalize our definition of memory activism through an analytical tool, in order to help identify memory activists and capture variations among them. The typology, presented in Figure 1, consists of the following three dimensions: (1) the most common types of relational roles memory activists use as a basis for their interventions: victims, resistors and heroes, entangled agents, and pragmatists; (2) memory activists' primary mode of interaction based on their vision of historical truth: warriors and pluralists; and (3) activists' understanding of temporality with respect to the historical past in question: events that have ended or that are still ongoing. All three dimensions are premised on our fundamental assumption that the concept of the memory activist is a relational one: it is neither static nor timeless but is rather situated in relationship with shifting constellations of actors and environments and the symbolic meanings about the past that they help to (re)produce.

\section{Roles}

The typology of activist relational roles is inspired by the social interactionist approach of Erving Goffman (1961), which views the presentation of one's self through the choice and performance of a cultural role as a central component of social interaction in everyday life. Drawing on our extensive review of existing empirical studies of memory activism, our typology lists the main roles that memory activists take in real mnemonic struggles. The roles are often related to actors' biographical experiences, but not fully determined by them. Instead, taking the role of a victim or a pragmatist relates to how an actor understands and presents herself to others: Those who perpetrated mass violence can claim that they are victims and victims of such atrocities can act as resistors or pragmatists. Because this presentation of self is rooted in symbolic interaction, playing a role successfully depends on whether society accepts one's choice and performance as legitimate or not and may change over time. Each of the four roles includes symbolic meaning, cultural capital, authority, and legitimacy that are particular to the culture in which memory activist groups operate, including in transnational networks. The central roles of memory activists appear on the left-hand column of Figure 1.

Victims: Actors whose primary motivation for activism is grounded in suffering. Their claims are usually linked to personal or familial experiences that directly link activists to historical events, though this link can be of variable factual strength. Victimhood status is often the basis for symbolic or material redress-claims and can mean a significant level of legitimacy, which is 
grounded in authenticity and the ability to speak with authority about trauma and legacy. However, the actions of those who often enjoy near-unassailable legitimacy due to their historical experience, do not necessarily advance peace, as Jie-Hyun Lim (2020) has contended. Moreover, the role of "victim" is not automatic (as none of these roles are), but rather requires active positioning on the part of the activist.

Resistors and heroes: Actors who fashion themselves as active and moral participants in historical events rather than as principled observers or as victims for instance. This category can include both past and present dissidents, resistance fighters or veterans, and others whose interpretations of the past have been contested in the past or are being contested in the present. Thus, a survivor may choose not to emphasize their victimization, but instead their ability to defy the odds and whose mere survival is an act of resistance against genocidal intentions. Resistance or heroism may come with its own advantages in terms of legitimacy and cultural power, depending in part on the specific cultural context. For example, the mantle of "hero" is one that holds much more cultural weight in the United States than in Germany.

Entangled agents: Actors who are temporally or geographically distant from the historical events that they reference, but that they nevertheless feel responsible for. We draw here centrally on Michael Rothberg's (2019) work on implicated subjects, but extend the category to include not only those who feel responsible for past injustices, but also those who see themselves connected to their "heritage" and feel the need to defend it against change. Rothberg (2019) argues that implicated subjects occupy "positions aligned with power and privilege without being themselves direct agents of harm" (p. 1) and who act due to their accountability and through their own privileged position. They might be seen as adopting the stance of a repentant perpetrator, without themselves being directly involved in any crime. However, we also regard memory activists as "entangled agents" when they argue for the need to defend a heritage to which they may not be connected directly. For example, campaigners in the United Kingdom who defend or seek to dismantle statues linked to British imperial legacies are defined as "entangled agents" irrespective of which side of the political argument they take.

Pragmatists: Actors who emphasize their lack of direct connection to or emotional involvement with the past in question as a source of legitimacy. These actors claim to have become activists due to more general commitments such as to democratic norms or to professional standards and often seek to function as mediators. This position is no less rooted in biographical experience than the other types of agents: pragmatists may have learned through personal experience that the representation of the past is crucial to the defense of human rights in the presence or their own life might have taught them the importance of pragmatic interaction. In other words, what matters here is again not what an individual has experienced, but which role they choose to adopt and whether this role is believable for a broader public. We argue that this category is important partly because it is often, though not exclusively, claimed by "experts" (historians, academics, memorial officials) who turn into activists but derive legitimacy from professional standards and training.

\section{Modes of interaction}

The second dimension of our typology addresses the complex interactions in which memory engage with various actors, drawing on the work of Jan Kubik and Michael Bernhard. They 
distinguish memory actors based on their relations to other actors, labeling them according to the choices these actors make within their constraints (Kubik and Bernhard, 2014): "warriors" regard their own interpretation of history as the only truth, while "pluralists" fundamentally believe that there is room for multiple approaches to the past, making them tolerant of others' positions. These two stances thus crucially shape the interaction between various actors, as well as their practices and strategies, and are essential to the comparative study of memory activists. Importantly, Kubik and Bernhard distinguish what warriors and pluralists believe about how the "mnemonic contest" is to be carried out. Memory activists can operate according to either mode of interaction, regardless of which of the roles we have identified they espouse. However, some roles lend themselves more readily to a warrior, others to a pluralist stance. Thus, activists who strongly identify with victimhood may be less willing to grant legitimacy to alternative versions of history, while pragmatists might be more inclined to pluralism - if only to underpin their legitimacy as neutral parties. Nevertheless, modes of interaction are not inextricably linked to certain roles and we can find cases of pluralist victims and pragmatist warriors, as we show below. The modes of interacton appear in the first row of Figure 1.

\section{Notions of temporality}

For scholars of memory activism, the question of temporality arises in several significant ways, yet what we are interested in here is a specific dimension: how temporality figures in activists' model for change - how activists themselves frame temporality with respect to the past that they are referencing, and particularly how their perception of temporal distance shapes their aims and practices. While the present and future are always the focal point from which the past is addressed (Gutman et al., 2010; Halbwachs, 1992), the stakes of changing memory from below in the face of ongoing violence and polarization are much higher than when the events have long ended. Between these two poles of temporal distance from the events remembered lie dissimilar risks that shape memory activist efforts in a significant manner. When the past has ended, for example, in postconflict societies, remembering and "coming to terms" with the past are often employed to make sure that an event that had ended will "never again" take place. When events are still ongoing, for example, during conflict, memory activism is an effort against the inevitability of events, and it works to correct what can still be reversed or to monitor and remember in order to prepare a record for the future. Such memory activist work during conflict has proved significant in Serbia for example, when the transition to democratic rule had finally arrived (Fridman, 2020; Katriel and Shavit, 2011). Memory activists who object to changing the course of ongoing events, however, similarly engage the (present-)past with expediency to defend the continuation of events. It is important to stress that in many cases, activists' understanding of whether "the past has passed" is part and parcel of their practice. For instance, present-day advocates for decolonization argue that colonial violence has indeed not ended but is ongoing. Notions of temporality appear in the second row of Figure 1.

In what follows, we use empirical examples to explain how this typology can be used to analyze specific case studies or for comparative research on memory activism. We lead with the roles and incorporate the two other dimensions into the explanation. 


\begin{tabular}{|c|c|c|c|c|}
\hline \multirow{2}{*}{\begin{tabular}{|l|}
\multicolumn{1}{|c|}{ Mode } \\
Role/ \\
Temporality
\end{tabular}} & \multicolumn{2}{|c|}{ Warriors } & \multicolumn{2}{|c|}{ Pluralists } \\
\hline & $\begin{array}{l}\text { The past has } \\
\text { ended }\end{array}$ & $\begin{array}{l}\text { The past is } \\
\text { ongoing }\end{array}$ & $\begin{array}{l}\text { The past has } \\
\text { ended }\end{array}$ & $\begin{array}{l}\text { The past is } \\
\text { ongoing }\end{array}$ \\
\hline Victims & $\begin{array}{l}\text { Association for the } \\
\text { Recovery of } \\
\text { Historical Memory, } \\
\text { Spain }\end{array}$ & $\begin{array}{l}\text { Memorial to the } \\
\text { Victims of } \\
\text { Violence, Mexico }\end{array}$ & $\begin{array}{l}\text { Reconciliatory } \\
\text { tours of the } \\
\text { Sudetenland by } \\
\text { German and } \\
\text { Czech activists }\end{array}$ & $\begin{array}{l}\text { Widows Against } \\
\text { Violence } \\
\text { Empower, } \\
\text { Northern Ireland }\end{array}$ \\
\hline $\begin{array}{l}\text { Resistors \& } \\
\text { heroes }\end{array}$ & $\begin{array}{l}\text { Former members } \\
\text { of the GDR regime } \\
\text { and former political } \\
\text { prisoners, } \\
\text { Germany }\end{array}$ & $\begin{array}{l}\text { The Legacy } \\
\text { Museum in } \\
\text { Montgomery, USA }\end{array}$ & $\begin{array}{l}\text { Hiroshima- } \\
\text { Auschwitz Peace } \\
\text { March }\end{array}$ & $\begin{array}{l}\text { Indigenous } \\
\text { memory } \\
\text { activists, } \\
\text { Canada }\end{array}$ \\
\hline $\begin{array}{l}\text { Entangled } \\
\text { agents }\end{array}$ & $\begin{array}{l}\text { United Daughters } \\
\text { of the } \\
\text { Confederacy, USA }\end{array}$ & $\begin{array}{l}\text { "We are not } \\
\text { Trayvon Martin," } \\
\text { USA }\end{array}$ & $\begin{array}{l}\text { Jewish Revival } \\
\text { activism, Poland }\end{array}$ & $\begin{array}{l}\text { Nakba Memory } \\
\text { Activism, Israel }\end{array}$ \\
\hline Pragmatists & $\begin{array}{l}\text { Hubertus Knabe } \\
\text { and others in GDR } \\
\text { memory politics }\end{array}$ & $\begin{array}{l}\text { Filmmaker Joshua } \\
\text { Oppenheim on } \\
\text { anti-communist } \\
\text { violence in } \\
\text { Indonesia }\end{array}$ & $\begin{array}{l}\text { Institutional } \\
\text { leaders turned } \\
\text { activists for GDR } \\
\text { memory }\end{array}$ & \begin{tabular}{|l|} 
International \\
Center for \\
Transitional \\
Justice
\end{tabular} \\
\hline
\end{tabular}

Figure 1. A typology of memory activists: roles, modes of interaction and notions of temporality.

\section{Putting the typology to work}

\section{Victims}

At the intersection of a victim role, a past that has ended, and a warrior mode of interaction is the Association for the Recovery of Historical Memory (ARMH) in Spain. This association represents the families of the victims of Francoist violence and its goal is to remember the "disappeared" victims of Franco's regime (1936-1975). Since 2000, it has used exhumations of mass graves to force the state to document, remember, and compensate the victims or their families. The ARMH acts as a warrior in Spanish memory politics about the past at issue: its members interact with Franco supporters, the Church, and the state with the objective of exposing a single historicalscientific truth about the past as the only legitimate option against state silencing and right-wing denial (Baer and Sznaider, 2017; Boyd, 2008; Ferrandiz, 2019; Jerez- Farrán and Amago, 2010).

In the next cell to the right is an example of memory activists that similarly take a victim role and a warrior mode of interaction that seeks the historical truth, but differs in its temporality; it takes place when violence is still ongoing. These are memory activists who advocate for Mexico's Memorial to the Victims of Violence (MVVM). MVVM act on behalf of the victims and their families and their goals extend beyond commemoration to an immediate political change of state 
policy (Nienass and Délano Alonso, 2019). Fighting the states' so-called "War on Drugs" policy, activists act as warriors who see any other interpretation of violence, primarily by the state, as denial that enables the ongoing state of crisis to continue.

However, "victims" can also act as pluralists as the next set of examples shows: Czech and German nationals have been touring the Sudetenland together since 2005 in order to remember the expulsion of around 3 million Germans by the Czech government in 1945-1946 (http://www.antikomplex.cz/cyklovylety-do-sudet.html). Both Czechs and Germans participants see themselves as victims of this historical event, yet they take a pluralist mode of interaction and advocate for a shared learning of the contested past for the purpose of reconciliation (Gutman, 2018).

Another example of a "pluralist" memory activist group has been formed during the conflict in Northern Ireland: "Widows Against Violence Empower (WAVE) Trauma Center," was founded in 1991, by eight women who lost their partner in the then still ongoing intercommunal violence known as "the Troubles" (1968-1998). Self-identifying as a victim group, the founders had a pluralist, cross-community aim - to provide care, support, and empowerment to other women who were widowed by this conflict. Today, it is the largest cross-community victims' group in the country (http://wavetraumacentre.org.uk/). ${ }^{2}$

\section{Resistors and heroes}

Our example for activists who take the role of resistors or heroes with a warrior stance while acknowledging the end of the history in question is the repeated clash between former political prisoners in East Germany (the German Democratic Republic, or GDR, 1949-1990) and the sometimes vocal appearance of unrepentant former Stasi officers during commemorative events, who claim that their history has been misrepresented in unified Germany. The former Stasi officers are an example of memory activists who are viewed publicly as perpetrators, but who see themselves as heroes (as they clearly identify with the former regime) or resistors to the new order. Those who were incarcerated in GDR prisons identify as victims, but also often as resistors, who actively fought against both the GDR regime and against what they see as a sidelining of this past today. Both sides appear as warriors as they insist on the unequivocal validity of their interpretation of history, to the exclusion of alternatives. Studying these (otherwise highly divergent) types of warrior activists side-by-side allows for a systematic examination of the discourses and strategies employed in the field of GDR memory politics. Comparing memory activists' modes of interaction in light of their public roles can reveal whether a warrior mode of interaction taken on by a former regime supporter contributes to victims of that regime taking on a warrior position as well, which in turn may result in an escalation of the memory conflict.

Our case study for resistors who take a warrior stance and regard the past as ongoing is the Equal Justice Initiative's (EJI) National Memorial for Peace and Justice and Legacy Museum in Montgomery Alabama, which opened in 2018. EJI was founded by lawyer Bryan Stevenson in 1989 and has worked to support those wronged by the US criminal justice system. According to Stevenson (2014), facing the history of slavery, lynching, and segregation is a key to addressing racial injustice and violence in the present. Alison Landsberg (forthcoming) argues that "rather than positing a historical break between the past and the present, the museum aims to make legible a fundamental continuity." The permanent exhibit, entitled "From Enslavement to Mass Incarceration," is explicitly forward-looking with an unapologetic standpoint on the interpretation of American history. Thus, these activists are warriors in the sense that they unequivocally advocate for a particular reading of history that centers attention on the ongoing violence against Black communities. This reading also reimagines the activists' memory practice as one of strategic resistance against both the previously dominant narrative of white heritage and the discourse of an 
uplifting and largely completed struggle of African American civil rights heroes. The past is seen as ongoing; indeed, the Legacy exhibit begins with the heading "Slavery did not end. It evolved" (Equal Justice Initiative, The Legacy Museum Book, 2018).

An example of resistors who act as pluralists for a past that is over is the 1962-1963 HiroshimaAuschwitz Peace March. The initiator, veteran of the Japanese imperial army and Buddhist monk Satō Gyōtsū, took the position of both a victim of the nuclear bomb and a resistor to his country's aggression in the Second World War in order "to unite the victims and places of tragedy" of the war (Hiroshima-Auschwitzu Heiwa Koshin, Newsletter No. 1). Together with three Japanese students, Gyōtsū headed the 3000-km procession, visiting war and memory sites from Hiroshima to Auschwitz-Birkenau. The organizers emphasized the unity of war victims and plurality of victim-witness voices, from both sides of the victim/victimizer spectrum, as a basis for world peace (Zwigenberg, 2013). Some of the war victims the marchers met rejected their contradictory public role (resistor to war) and peaceful and pluralist message. For example, in Singapore (May 1962), they were perceived as Japanese aggressors (Ibid.).

In the past decade or so, there has been a surge of Indigenous activism in Canada, some elements of which explicitly take the form of memory activism. Campaigns such as \#idlenomore, \#MMIWG (Missing and Murdered Indigenous Women and Girls), and \#Resistance150 (in response to Canada's celebration of the anniversary of Confederation in 2017) have demanded a new reckoning with the legacies of the Residential School system, the Indian Act, and centuries of colonialism. Crucially, these activists have insisted that structural racism and violence against Indigenous communities is ongoing and that settler society continues to benefit. They employ both conventional memory practices (demands to change museums' approaches to Canadian history, dismantling of statues, supporting alternative historical narratives) and traditions such as Rounddances and Powwows, which can be regarded as performative mnemonic practices. Activists are categorized as pluralist resistors as they emphasize their opposition to the Canadian settler regime and the importance of rediscovering Indigenous ways of knowing and of organizing governance, while also engaging with the politics of reconciliation and welcoming settler allyship.

\section{Entangled agents}

Next, we bring together memory activists who take on the role of entangled agents, first examining activists who act as warriors in their commemoration of a past that has ended. Along with other long-existing Southern "heritage" organizations in the United States, the United Daughters of the Confederacy's (UDC) purpose since its creation in 1894 has been the commemoration of Confederate Civil War soldiers. Closely allied to the terrorist Ku Klux Klan in the early-twentieth century, the group promoted a narrative of white supremacy and of the "Lost Cause" of the Confederacy as a heroic and legitimate one through the primary vehicle of building monuments, though it has tempered its approach since then. During the protests triggered by the murder of George Floyd, the UDC headquarters in Richmond were targeted (https://www.washingtonpost.com/history/2020/05/31/confederate-statues-vandalized-protestersgeorge-floyd/). In response to this and the general movement against Confederate symbols, the President-General of the Daughters, Linda Edwards, issued a statement "denouncing hate groups and affirming that Confederate memorial statues and monuments are part of our shared American history and should remain in place." Though there was some token acknowledgment that these "markers are viewed as divisive," the UDC took a warrior stance to American history. They take the role of "entangled agents" as ancestors of Confederate soldiers "who, like our statues, have stayed quietly in the background, never engaging in public controversy" and argue that we should "not sit in judgment of them nor do we impose the standards of the $19^{\text {th }}$ century on Americans of 
the $21^{\text {st }}$ century" (https://hqudc.org/). Insistence that the past has passed is thus key to perpetuating the narrative that supports white supremacy in the guise of honoring a joint heritage.

Our case study for memory-activist entangled agents who take a warrior stance and regard the past as ongoing is the "We are not Trayvon Martin" antiracist website and hashtag campaign (\#NotTrayvon), which was established in the United States in 2013. Martin was an African American teenager who was killed on 2012 in Florida by a neighborhood vigilante. The acquittal of his killer a year later sparked the Black Lives Matter protest. Instead of direct solidarity and identification, these non-Black activists asserted a "differentiated solidarity" with Martin through calling attention to their privileged position (Rothberg, 2019). Their aim is both to mourn Martin's death and to reveal their own implication in the histories and structures that made that death possible, as well as the ongoing violence against Blacks in the United States (Rothberg, 2019).

The next set of examples in the same row demonstrates an entangled agent position with a pluralist mode of interaction. Catholic-Poles who publicly commemorate the Jewish past of their country since 1990s mark a past that has ended. "The Jewish Revival" includes hundreds of local initiatives to restore former Jewish sites, to organize tours, exhibits, and cultural festivals, to collect testimonies and to engage the young generation in learning about their local Jewish history (Gutman, 2018; Holc, 2018; Zubrzycki, 2012). Although they mourn the loss of the large Jewish community in the Holocaust and acknowledge the role of Poles in the fate of Jews, their aim is to restore a multicultural past, a past in which Poles host different minorities, including Jews (Gutman, 2018).

Jewish-Israeli memory activists who remember the Palestinian displacement (known as alNakba) by Jewish-Israeli military forces since 1948 identify as entangled agents who commemorate as pluralists a past that has ended. These memory activists seek to take responsibility for their national community's wrongdoing while the conflict with the Palestinians is ongoing. Their pluralist mode of interaction takes into account Israel's official national narrative as well as the Palestinian national narrative but offers a different interpretation of the past in order to project a different vision for redress and reconciliation in the future (Gutman, 2017).

\section{Pragmatists}

Unsurprisingly, the pragmatist role lends itself more readily to a pluralist mode of interaction because openness to alternative versions of the past and to dialogue reinforces an actor's claim to pragmatism. Nevertheless, we do find some instances of warriors who seek the pragmatist mantle.

One key driver of commemoration in the former GDR are pluralist pragmatists who regard this history as past. These are associations led by individuals, who either do not have biographical experience with repression in the GDR or do not chose to emphasize it. For example, Peter Boeger, who leads the initiative for the Checkpoint Bravo (former crossing point on the motorway into Berlin) memorial, got involved because he lived close by. In addition, he had a professional interest as an employee of the agency in charge of the GDR regime's secret police files. Similarly, the founder of the association that initiated the Marienfelde Refugee Center Museum, Harald Fiss, had been the bureaucrat in charge of the Center in 1989/1990, and then decided to become engaged in its commemoration. Both of these actors have biographical links to German cold war era history, but both take a pragmatist stance, demanding memorialization for principled reasons. And both, due to this positioning, have acted as pluralist mediators between other, more warrior-like, memory activists, and the state in the process of negotiations over how this memory landscape should be governed (Wüstenberg, 2017: 227).

Pragmatist activists have also adopted a pluralist approach while trying to mediate memory in active conflict. The International Center for Transitional Justice (ICTJ) is a New York-based independent organization that develops tools for truth-seeking efforts around the world. Its truth 
and memory program provides support for using memory to address difficult histories in and after conflict. The organization was involved in the design of a truth commission for the prolonged civil violence in Columbia, during the peace talks between the government and the Revolutionary Armed Forces rebel group. The organization took a pluralist stance, providing "technical advice to all parties to ensure that the final peace agreement effectively addresses and incorporates truth and memory concerns" (https://www.ictj.org/our-work/transitional-justice-issues/truth-and-memory). In Lebanon, where the legacy of the civil war (1975-1990) continues to incite violence and destabilize the political system, ICTJ worked with civil society groups to facilitate the collection of testimonies on the war from members of the various rival groups (Badna Naaref-We want to Know in Arabic), and invited the young generation to reflect on the war's continuing impact in its the 25th anniversary (https://www.ictj.org/multimedia/photo/war-i-see-it-photo-contestexhibition).

Warrior pragmatists are more unusual. However, in the context of memory politics concerning the GDR, there are actors who qualify. Most well-known is Hubertus Knabe, the former Scientific Director of the Stasi prison memorial in Berlin-Hohenschönhausen (2001-2019), who-while maintaining the mantle of a professional and pragmatist - became one of the most ardent defenders of an uncompromising anti-communist narrative about the history of the two Germanies. In addition to pursuing an unconventional approach to historical education at Hohenschönhausen, Knabe published several books "exposing" the continued power of former members of the East German secret police and thus was celebrated among former political prisoners of the GDR. Removed from his position due to a sexual harassment scandal in 2019 , he has continued his activism. A similarly positioned actor is Siegfried Reiprich, a former political prisoner in the GDR and head of governmental Saxon Foundation of Memorials until he was removed in November 2020 due to controversial tweets. However, in interviews, Reiprich clearly presented himself as a pragmatist who sought to mediate between different victim groups (Wüstenberg, 2019).

Joshua Oppenheimer, an award-winning filmmaker, is an example for a warrior pragmatist who targets a past that he portrays as ongoing, since its perpetrators are still in power. In his Oscarnominated "The Act of Killing" (2012), Oppenheimer documented the anti-communist mass killings by the military and paramilitary death squads in Indonesia in 1965, provocatively giving the stage to the perpetrators in order to break the silencing of the victims:

[...] the film is essentially not about what happened in 1965 , but rather about a regime in which genocide has, paradoxically, been effaced and celebrated - in order to keep the survivors terrified, the public brainwashed, and the perpetrators able to live with themselves.

In this this interview, Oppenheimer thus indicates his warrior position regarding what he views as the continuation of a threatening regime (Melvin, 2013).

\section{Conclusion}

Our typology supports the analysis of memory activists as key actors in the politics of the past in numerous ways. First, the typology can be used to systematize analysis of a particular memorypolitical arena to better understand clashes between various activists and possible alliances between them, as we have demonstrated through the inclusion of several different types of activists in the politics over the remembrance of the GDR. Second, the typology allows a consideration of the changing place of activists in the typology over time to understand their evolution and positioning vis-à-vis memory political developments writ-large. For example, if a particular group shifts from a warrior to a pluralist stance or from viewing the past as ongoing to "over," this raises important questions about those activists' strategies and their meaning-making with respect to 
commemorative practice. Third, when arranged with the help of our typology, a researcher might be prompted to compare similar cases of memory activists that are placed in the same or adjacent cells. Thus, the UDC and anti-Confederate memory activists would both be defined as entangled agents, who are warriors and regard the past as passed. However, they are on opposite ends of this particular struggle, so what are the implications for their interaction and for their perception in the wider society? Fourth, because the typology allows the comparison of cases in different geographies, time periods, or mnemo-politics, it facilitates creative thinking and collaborative research across fields and area studies that often do not engage with each other. Finally, the typology can help activists themselves understand better the landscape within which they are operating and may help them (re)consider strategic choices about the roles or interactional stance they adopt.

Our matrix, as these examples show, provides researchers with a rigorous tool for comparing different types of memory activists, or a single case over time, and the ability to include variations and nuances in each case study. This comparative agility has often been missing from memory studies, and prevented a systematic examination of certain research questions. Moreover, we argue that it is precisely the value-neutrality of our typology-its ability to accommodate memory activists from the entire political spectrum - that will ultimately support scholarship that is underpinned by an explicit normative commitment to pluralist and democratic memory politics.

\section{Acknowledgements}

The authors would like to thank the editors of Memory Studies and the anonymous reviewers for their insightful comments. They would also like to thank Boaz Nissan-Cohen, Bill Niven, and Chris Reynolds for their valuable suggestions. They are grateful to Elazar Barkan and the participants of the international workshop on "Memory Activism in Comparative Perspective" at Columbia University in November 2018, for engaging in early discussions with them that helped lay the groundwork for their article.

\section{Funding}

The author(s) disclosed receipt of the following financial support for the research, authorship, and/or publication of this article: The authors gratefully acknowledge funding from the Fritz-Thyssen-Foundation for that workshop.

\section{ORCID iDs}

Yifat Gutman (D) https://orcid.org/0000-0002-4742-6004

Jenny Wüstenberg (D) https://orcid.org/0000-0002-0405-3607

\section{Notes}

1. We thank Bill Niven for his insightful point here.

2. We thank Chris Reynolds for alerting us to this case.

\section{References}

Alexander C (2006) The Civil Sphere. Oxford: Oxford University Press.

Armstrong EA and Crage SM (2006) Movements and memory: the making of the stonewall myth. American Sociological Review 71(5): 724-751.

Assmann J (2010) Communicative and cultural memory. In: Erll A and Nünning A (eds) Cultural Memory Studies: An International and Interdisciplinary Handbook. Berlin: De Gruyter, pp. 109-118.

Baer A and Sznaider N (2017) Memory and Forgetting in the Post-Holocaust Era. London: Routledge.

Baumgarten B (2017) The children of the carnation revolution? Connections between Portugal's anti-austerity movement and the revolutionary period 1974/1975. Social Movement Studies 16(1): 51-63. 
Bennett L and Segerberg A (2013) The Logic of Connective Action: Digital Media and the Personalization of Contentious Politics. Cambridge: Cambridge University Press.

Berger S, Scalmer S and Wicke C (2021) Memory and social movements: An introduction. In: Berger S, Scalmer S and Wicke C (eds) Remembering Social Movements: Activism and Memory. New York: Routledge, 1-25.

Björkdahl A and Kappler S (2019) The creation of transnational memory spaces: professionalization and commercialization. International Journal of Politics, Culture, and Society 32: 383-401.

Bosco FJ (2004) Human rights politics and scaled performances of memory: conflicts among the Madres de Plaza de Mayo in Argentina. Social \& Cultural Geography 5(3): 381-402.

Boyd CP (2008) The politics of history and memory in democratic Spain. The Annals of the American Academy of Political and Social Science 617(1): 133-148.

Brubaker R (1996) Nationalism Reframed: Nationhood and the National Question in the New Europe. Cambridge: Cambridge University Press.

Buda D-M (2015) Affective Tourism: Dark Routes in Conflict. London: Routledge.

Bukowiecki L, Wawrzyniak J and Wróblewska M (2020) Duality of Decolonizing: Artists' Memory Activism in Warsaw. Heritage \& society 13 (1-2): 32-52.

Chidgey R (2015) “A modest reminder": performing suffragette memory in a British feminist webzine. In: Reading A and Katriel T (eds) Cultural Memories of Nonviolent Struggles. London: Palgrave Macmillan, pp. 52-70.

Daphi P (2017) Becoming a Movement. Identity, Narrative and Memory in the European Global Justice Movement. London: Rowman \& Littlefield.

Daphi P and Zamponi L (2019) Exploring the movement-memory nexus: insights and ways forward. Mobilization: An International Quarterly 24(4): 399-417.

Dybris McQuaid S and Gensburger S (2019) Administrations of memory: transcending the nation and bringing back the state in memory studies. International Journal of Politics, Culture and Society 32(2): 125-143.

Equal Justice Initiative (2018) The Legacy Museum. Montgomery, AL: Equal Justice Initiative.

Ferrandiz P (2019) Unburials, generals, and phantom militarism: engaging with the Spanish Civil War legacy. Current Anthropology 60: S62-S76.

Fridman O (2020) Conflict, memory, and memory activism: dealing with difficult pasts. In: Richmond O and Visoka G (eds) The Palgrave Encyclopedia of Peace and Conflict Studies. Cham: Palgrave Macmillan. Published online: https://doi.org/10.1007/978-3-030-11795-5 38-1.

Fridman O and Ristić K (2020) Online transnational memory activism and commemoration: the case of the White Armband Day. In: Wüstenberg J and Sierp A (eds) Agency in Transnational Memory Politics. New York: Berghahn Books, 68-91.

Gans HJ (1997) Toward a reconciliation of "assimilation" and "pluralism": the interplay of acculturation and ethnic retention. International Migration Review 31(4): 875-892.

Gluck C (2007) Operations of memory: comfort women and the world. In: Jager SM and Mitter R (eds) Ruptured Histories: War Memory and the Post-Cold War in Asia. Cambridge, MA: Harvard University Press, $47-77$

Goffman E (1961) Asylums. New York: Knopf.

Gongaware TB (2011) Keying the past to the present: collective memories and continuity in collective identity change. Social Movement Studies 10(1): 39-54.

Gutman Y (2017) Memory Activism: Reimagining the past for the Future in Israel-Palestine. Nashville, TN: Vanderbildt University Press.

Gutman Y (2018) The Role of Memory Activism in Reconciliation Processes in Comparative Perspective. Tel Aviv, Israel: Tami Steinmetz Center for Peace Studies, Tel Aviv University Press (In Hebrew).

Gutman Y, Brown AD and Sodaro A (2010) Memory and the Future: Transnational Politics, Ethics and Society. London: Palgrave Macmillan.

Hajek A (2013) Negotiating Memories of Protest in Western Europe. London: Palgrave Macmillan.

Hajek A (2016) Feminist impact: exploring the cultural memory of second-wave feminism in contemporary Italy. In: Hajek A, Lohmeier C and Pentzold C (eds) Memory in a Mediated World: Remembrance and Reconstruction. London: Palgrave Macmillan, pp. 129-141.

Halbwachs M (1992) On Collective Memory. Chicago, IL: University of Chicago Press. 
Harris FC (2006) It takes a tragedy to arouse them: collective memory and collective action during the civil rights movement. Social Movement Studies 5(1): 19-43.

Holc JP (2018) The Politics of Trauma and Memory Activism: Polish-Jewish Relations Today. Basingstoke: Palgrave Macmillan.

Jasper J (2004) A strategic approach to collective action: looking for agency in social-movement choices. Mobilization: An International Journal 9(1): 1-16.

Jelin E (2003) State Repression and the Labors of Memory. Minneapolis, MN: University of Minnesota Press.

Jerez- Farrán C and Amago S (2010) Unearthing Franco's Legacy: Mass Graves and the Recovery of Historical Memory in Spain. Notre Dame, IN: University of Notre Dame Press.

Katriel T and Shavit N (2011) Between moral activism and archival memory: the testimonial project of breaking the silence. In: Neiger M, Meyers O and Zandberg E (eds) On Media Memory Collective Memory in a New Media Age. London: Palgrave Macmillan, pp. 77-87.

Kovras I (2017) Grassroots Activism and the Evolution of Transitional Justice: The Families of the Disappeared. Cambridge: Cambridge University Press.

Kubal T and Becerra R (2014) Social movements and collective memory. Sociology Compass 8(6): 865-875.

Kubik J and Bernhard M (2014) A theory of the politics of memory. In: Bernhard M and Kubik J (eds) Twenty Years after Communism. the Politics of Memory and Commemoration. Oxford: Oxford University Press, pp. 7-34.

Landsberg A (forthcoming) Memory vs history: the politics of temporality at the legacy museum in montgomery Alabama. In: Gutman Y and Wüstenberg J (eds) The Routledge Handbook of Memory Activism. London: Routledge.

Lim J-H (2010) Victimhood nationalism in contested memories: national mourning and global accountability. In: Assmann A and Conrad S (eds) Memory in a Global Age: Discourses, Practices and Trajectories. Basingstoke: Palgrave Macmillan, pp. 138-162.

Melvin J (2013) An interview with Joshua Oppenheimer. Inside Indonesia 112, published online 27 April. [https://www.insideindonesia.org/an-interview-with-joshua-oppenheimer].

Merrill S, Keightley E and Daphi P (2020) Introduction: the digital memory work practices of social movements. In: Merrill S, Keightley E and Daphi P (eds) Social Movements, Cultural Memory and Digital Media. Basingstoke: Palgrave Macmillan, pp. 1-30.

Mitchell T (1999) Society, economy, and the state effect. In: Steinmetz G (ed.) State/Culture: State-Formation after the Cultural Turn. Ithaca, NY: Cornell University Press, pp. 76-97.

Mpofu S (2014) Public and Diasporic Online Media in the Discursive Construction of National Identity: A Case of "Zimbabwe." Witwatersrand, South Africa: University of the Witwatersrand.

Nienass B and Délano Alonso A (2019) Mexico City's memorial to the victims of violence and the facade of participation. In: Apsel J and Sodaro A (eds) Museums as Sites of Persuasion: Politics, Memory and Human Rights. London: Routledge, pp. 153-173.

Oppenheimer, Joshua, Anonymous, and Christine Cynn (2012) The Act of Killing (Denmark: 115 min).

Pearce SC (2015) Who owns a movement's memory? The case of Poland's solidarity. In: Reading A and Katriel T (eds) Cultural Memories of Nonviolent Struggles. London: Palgrave Macmillan, pp. 166-187.

Pettai E-C (2020) Historians, public history, and transitional justice: Baltic experiences. International Public History 3(2): 2020-2010.

Polletta F and Jasper JM (2001) Collective identity and social movements. Annual Review of Sociology 27: 283-305.

Rigney A (2016) Differential memorability and transnational activism: bloody Sunday, 1887-2016. Australian Humanities Review 59: 77-95.

Rigney A (2018) Remembering hope: transnational activism beyond the traumatic. Memory Studies 11(3): $368-380$.

Rothberg M (2019) The Implicated Subject. beyond Victims and Perpetrators. Stanford, CA: Stanford University Press.

Smit R (2020) Connective memory work on justice for Mike Brown. In: Merrill S, Keightley E and Daphi P (eds) Social Movements, Cultural Memory and Digital Media. Basingstoke: Palgrave Macmillan, pp. 85108 .

Stevenson B (2014) Just Mercy: A Story of Justice and Redemption. New York: Spiegel \& Grau.

Swidler A (1986) Culture in action: symbols and strategies. American Sociological Review 51(2): 273-286. 
Szczepanka K (2014) The Politics of War Memory in Japan: Progressive Civil Society Groups and Contestation of Memory of the Asia-pacific War. New York: Routledge.

Tarrow S (1998) Power in Movement: Social Movements and Contentious Politics. Cambridge: Cambridge University Press.

van Dijck J (2007) Mediated Memories in the Digital Age. Stanford, CA: Stanford University Press.

Wagner-Pacifici R and Schwartz B (1991) The Vietnam veterans memorial: commemorating a difficult past. American Journal of Sociology 97(2): 376-420.

Warner M (2005) Publics and Counterpublics. Brooklyn, NY: Zone Books.

Wawrzyniak J (2015) Veterans, Victims, and Memory: The Politics of the Second World War in Communist Poland. Frankfurt: Peter Lang.

Whitlinger C (2019) The transformative capacity of commemoration: comparing mnemonic activism in Philadelphia, Mississippi. Mobilization: An International Quarterly 24(4): 455-474.

Wicke C (2021) Memory "within," "of" and "by" urban movements. In: Berger S, Scalmer S and Wicke C (eds) Remembering Social Movements. Activism and Memory. New York: Routledge, 133-155.

Wüstenberg J (2017) Civil Society and Memory in Postwar Germany. Cambridge: Cambridge University Press.

Wüstenberg J (2019) Pluralism, governance and the new right in German memory politics. German Politics and Society 37(132): 89-110.

Zamponi L (2018) Social Movements, Memory and Media: Narrative in Action in the Italian and Spanish Student Movements. Basingstoke: Palgrave Macmillan.

Zubrzycki G (2012) Religion, religious tradition, and nationalism: Jewish revival in Poland and "religious heritage" in Québec. Journal for the Scientific Study of Religion 51(3): 442-455.

Zwigenberg R (2013) The Hiroshima-Auschwitz peace march and the globalization of the "moral witness." Dapim: Studies on the Holocaust 27(3): 195-211.

\section{Author biographies}

Yifat Gutman is a Senior Lecturer in the Department of Sociology and Anthropology at Ben-Gurion University, Israel. Her current research focuses on memory activism and political change in and after conflict, as well as on memory laws. She is the author of Memory Activism: Reimagining the Past for the Future in Israel-Palestine (Vanderbilt University Press, 2017) and co-editor of the volume Memory and the Future: Transnational politics, ethics and society (Palgrave Macmillan, 2010).

Jenny Wüstenberg is Associate Professor of Twentieth Century History and Director of the Centre for Public History, Heritage and Memory at Nottingham Trent University, Co-President of the Memory Studies Association, and Action Chair of the COST Action on "Slow Memory." She is the author of Civil Society and Memory in Postwar Germany (Cambridge University Press 2017) and co-editor of Agency in Transnational Memory Politics (Berghahn 2020) and De-Commemoration (Berghahn 2022). Her current research examines the commemoration of family separation policies and institutional child abuse from a comparative perspective. 